\title{
Daldinia eschscholtzii (Ascomycota, Xylariaceae) isolated from the Brazilian Amazon: taxonomic features and mycelial growth conditions
}

\author{
Kamila Tomoko YUYAMA ${ }^{1,3}$, Jadergudson PEREIRA², Cristina Sayuri MAKI ${ }^{3}$, Noemia Kazue ISHIKAWA ${ }^{1}$

\section{ABSTRACT} \\ The Amazon has a high diversity of fungi, including species of the genus Daldinia (Ascomycota, Xylariaceae), which produce \\ secondary metabolites with recognized nematicidal and antimicrobial activity. The ecological role of Daldinia is important, \\ as stromata serve as refuges to many insects and arthropodes, and the fungi contribute to the degradation of vegetable organic \\ matter. The aim of this study was to analyze the taxonomic features and mycelial growth conditions in vitro of a Daldinia \\ specimen collected in the Brazilian Amazon. Morphological and molecular studies of the fungus identified it as D. eschscholtzii. \\ To evaluate mycelial growth, we cultivated the fungus at $20,25,30,35$, and $40{ }^{\circ} \mathrm{C}$ in malt extract-peptone agar (MEPA), \\ malt extract-peptone (MEP), potato dextrose (PD), and minimum medium (MM). The best mycelial growth occurred at \\ $35^{\circ} \mathrm{C}$, although the greatest amount of biomass was obtained at $25^{\circ} \mathrm{C}$ and $30^{\circ} \mathrm{C}$. PD proved to be the best medium for \\ biomass production.
}

KEYWORDS: Daldinia eschscholzii, fungal diversity, macrofungus, occurrence.

\section{Daldinia eschscholzii (Ascomycota, Xylariaceae) isolado na Amazônia brasileira: características taxonômicas e condições de crescimento micelial}

\begin{abstract}
RESUMO
A Amazônia apresenta alta diversidade de fungos, incluindo Daldinia (Ascomycota, Xylariaceae), cujas espécies produzem metabólitos secundários com reconhecida atividade antimicrobiana e nematicida. O papel ecológico é importante, visto que estromas servem de abrigo para muitos insetos e artrópodes, além de contribuir na degradaçáo da matéria orgânica vegetal. $\mathrm{O}$ objetivo desse estudo foi analizar as características taxonômicas e as condiçôes do crescimento micelial in vitro de um espécime de Daldinia coletado na Amazônia brasileira. Estudos morfológicos e moleculares do fungo o indetificaram como D. eschscholtzii. Para avaliaçáo do crescimento micelial o fungo foi cultivado nas temperaturas de $20,25,30,35$ e $40{ }^{\circ} \mathrm{C}$ e nos meios de cultura extrato de malte-peptona ágar (EMPA), extrato de malte-peptona (EMP), batata dextrose (BD) e meio mínimo (MM). $\mathrm{O}$ melhor crescimento micelial ocorreu a $35^{\circ} \mathrm{C}$, entretanto, a maior quantidade de biomassa foi obtida a 25 e $30^{\circ} \mathrm{C}$. O meio $\mathrm{BD}$ provou ser o melhor meio para produção de biomassa.
\end{abstract}

PALAVRAS-CHAVE: Daldinia eschscholzii, diversidade fúngica, macrofungos, ocorrência.

\footnotetext{
1 Instituto Nacional de Pesquisas da Amazônia. Avenida André Araújo, 2936, Aleixo, 69.060-001, Manaus-AM. Telefone: +55(92) 36431890. Fax: +55(92) 36431846. E-mail: noemia@inpa.gov.br

2 Universidade Estadual de Santa Cruz. Campus Soane Nazaré de Andrade. Rodovia llhéus-Itabuna, km 16, 45.662-900, Ilhéus-BA. Telefone: +55(73) 36805112 Fax: +55(73) 36805254 .E-mail: jader@uesc.br

3 Universidade Federal do Amazonas. Avenida General Rodrigo Otávio Jordão Ramos 6200 - Setor Sul, 69.077-000, Manaus-AM. Telefone: +55(92) 33054231. Fax: +55(92) 33054232. E-mail: cris.maki@gmail.com
} 


\section{INTRODUCTION}

Amazonian lignocellulolytic fungi, including species of Xylariaceae (Ascomycota) (Singer 1984; Braga-Neto 2007; Braga-Neto et al. 2008), are highly biodiverse and have important roles in decomposition and nutrient cycling (Singer and Araujo 1979; Singer et al. 1983; Luizão et al. 1999).

The genus Daldinia Ces. \& De Not., species of which are found frequently on the campus of the National Institute of Amazonian Research (INPA), differs from other Xylariaceae genera in having concentric zones inside the stroma (Ju et al. 1997, Stadler et al. 2001b).

Allport and Bu'lock (1958; 1960) first studied the chemical constituents of Daldinia concentrica (Bolton) Ces. \& De Not., identifying characteristic metabolites from the stroma and cultures. Several of these compounds showed antimicrobial and nematicidal activity (Anke et al. 1995). Studies with Daldinia spp. have revealed more than 20 new bioactive metabolites, including derivatives of benzofenones (Hashimoto et al. 1994a), azafilones, daldinins A-C (Hashimoto et al. 1994b), cytochalasans (Buchanan et al. 1995; 1996a, b; Hashimoto and Asakawa 1998), triterpenoids, concentricols (Stadler et al. 2001a; Quang et al. 2002a, b), daldiniapyrone, daldinones (Quang et al. 2002b), benzoquinones (Qin and Liu 2004a), esteroids (Qin and Liu 2004b), heptentriols (Wang and Liu 2004), diaporthins, orthosporins (Lee et al. 2006), and concentricolides (Qin et al. 2006).

Dalesconol A and B polyketides with immunosuppressive activity were initially isolated from $D$. eschscholtzii by Zhang and co-workers (2008). Two years later, daeschol A, dalesconol C, 2, 16-dihydroxyl-benzo[j]fluoranthene and dalmanol A were isolated by the first time from mantis-associated $D$. eschscholtzii (Zhang et al. 2011). Recently, helicascolide C, a new lactone with fungistatic activity against Cladosporium cucumerinum was isolated together with helicascolide A from an Indonesian marine algicolous-associated D. eschscholtzii strain (Tarman et al. 2012).

In addition to producing secondary metabolites, the stromata of Daldinia serve as a habitat for many arthropod species. In an analysis of $1000 \mathrm{D}$. concentrica stromata, Hingley (1971) found eggs, larvae, pupae, and adults from 120 arthropod species. He also reported a gradual reduction of the stromata of this fungus during spore dispersion, as several animals used the stromata for feeding, egg deposition and refuge. According to Johannesson (2000), the variety of secondary metabolites found probably correlates with the great number of animals living in the stromata. Another interesting aspect of Daldinia is the use of Daldinia. fissa Lloyd as food by people in Guatemala, where it is sold in public markets and eaten roasted with salt and lemon (Morales et al. 2006).

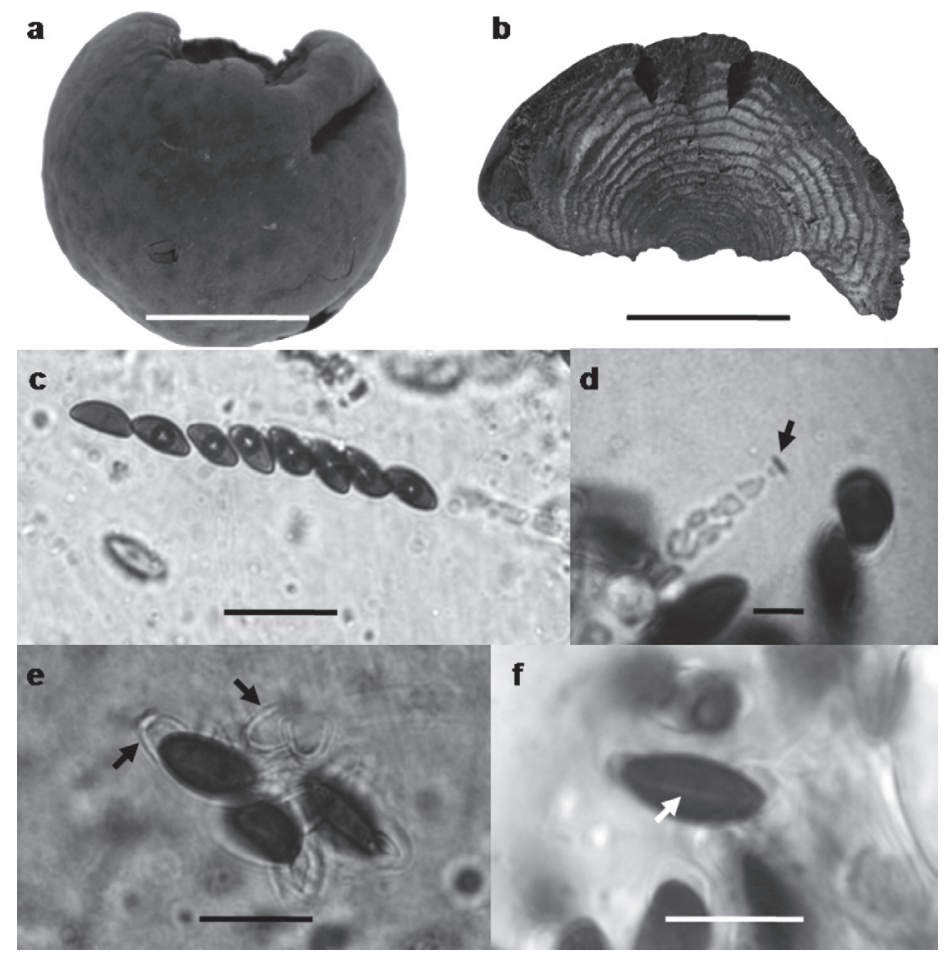

Figure 1 - Daldinia eschscholtzii (a) Upper view of stromata; (b) Cross-section of stroma, showing concentric zones; (c) Asci and ascospores; (d) Apical ring bluing in Melzer's iodine reagent (arrow); (e) Perispore dehiscent in 10\% KOH (arrows); (f) Ascospores showing straight germ slit spore-length on convex side (arrow). Bars: $a$ and $b=1 \mathrm{~cm} ; c=20 \mu \mathrm{m} ; \mathrm{d}=5 \mu \mathrm{m}$; e and $\mathrm{f}=10 \mu \mathrm{m}$. 
Considering the high biotechnological potential and ecological importance of Daldinia species, we investigated the taxonomic characteristics and in vitro mycelial growth of a Daldinia isolate collected in the Brazilian Amazon.

\section{MATERIALS AND METHODS}

On May 2008, a Daldinia specimen was collected from dead wood on Campus III of INPA $\left(03^{\circ} 05^{\prime} 53.4^{\prime \prime}\right.$, 5959'56.7” W; $70 \pm 5 \mathrm{~m}$ alt.), Manaus, Amazonas, Brazil. The fungus was isolated on potato dextrose agar medium (PDA; Acumedia ${ }^{\oplus}$, Lansing, Michigan, USA) with added penicillin $\left(2.8 \mu \mathrm{g} \mathrm{mL}{ }^{-1} ; F^{2} u k a^{\oplus}\right.$, China) and incubated in darkness for 14 days at $25^{\circ} \mathrm{C}$.

We characterized the isolate macroscopically in terms of its: shape, stroma size, perithecia and ostioles, coloration of stromata, and concentric zones. Microscopic characters there were analyzed included: shape, size and apical ring of the ascus in Melzer's iodine reagent; size, shape and color of ascospores and the germ slit; and perispore dehiscence in $10 \% \mathrm{KOH}$.

DNA from lyophilized mycelium of the specimen was extracted in liquid nitrogen for molecular analysis, and nucleic acids were extracted according to the adapted protocol of Ferreira and Grattapaglia (1998). The DNA was suspended in $50 \mu \mathrm{L}$ TE buffer (10 mM Tris-HCl, pH 8.0; 1 mM EDTA) and incubated at $37^{\circ} \mathrm{C}$ for $30 \mathrm{~min}$ after the addition of RNase A $\left(0.01 \mathrm{mg}_{\mu \mathrm{L}} \mathrm{L}^{-1}\right)$. After digestion, the DNA was quantified in $1 \%$ agarose gel-TAE, using intact $\lambda$-DNA (Invitrogen ${ }^{\circ}$, Carlsbad, California, USA) as the pattern and adjusted to a final concentration of $10 \mathrm{ng} \mathrm{mL}^{-1}$.

The ITS-5.8S and nLSU regions were amplified using the primers ITS1/ITS4 and LR16/LR5, respectively (White et al. 1990; Gardes and Bruns 1993; Moncalvo et al. 2000). The PCR reaction mixture contained 2.0 ng template DNA, 2.0 $\mathrm{U}$ Platinum ${ }^{\circ} \mathrm{Taq}$ DNA Polymerase (Invitrogen ${ }^{\circ}$, Carlsbad, California, USA), $0.2 \mathrm{mM}$ dNTP mix, $1.5 \mathrm{mM} \mathrm{MgCl}$, enzyme buffer and distilled water. It was further purified by passage through a Milli-Q filter system (Millipore, Barueri, Brazil) with $0.2 \mathrm{mM}$ of the selected beginning region and brought to a final volume of $50 \mu \mathrm{L}$. The PCR reaction was conducted on an automatic thermocycler (Eppendorf ${ }^{\circ}$, Hamburg, Germany), starting with 5-min denaturation cycle at $94^{\circ} \mathrm{C}, 40$ cycles of $40 \mathrm{sec}$ at $94^{\circ} \mathrm{C}, 30 \mathrm{sec}$ at $55^{\circ} \mathrm{C}$, and 60 sec at $72{ }^{\circ} \mathrm{C}$. Polymerization was ended at $72^{\circ} \mathrm{C}$ for $5 \mathrm{~min}$. The amplification products were applied to $1.5 \%$ agarose gelTAE containing $0.1 \mu \mathrm{g} \mathrm{mL}^{-1}$ ethidium bromide. The products were then purified using a Pure Link ${ }^{\mathrm{TM}}$ PCR Purification Kit (Invitrogen ${ }^{\circledR}$, Carlsbad, California, USA).

The amplified fragments were sequenced on an automatic sequencer (MegaBace 1000 Molecular Dynamics with DYEnamic ET Dye Terminator Cycle Sequencing), according to the manufacturer's instructions, using the primers ITS1, ITS4, LR16, and LR5 to sequence the samples in both directions.

The internal transcribed spacer (ITS) sequences of the specimen were compared with sequences in GenBank, using Blast to determine identity levels. To create a phylogenetic tree of Daldinia species, we used MEGA 5 software (www. megasoftware.net) and the neighbor-joining method with 1000 bootstrap repetitions, using Hypoxylon fragiforme (Pers.) J. Kickx f. (AY616690) as the outgroup.

Mycelial growth was evaluated at 20, 25, 30, 35 and 40 ${ }^{\circ} \mathrm{C}$. Culture discs ( $2 \mathrm{~mm}$ diameter) were transferred to Petri dishes $(9 \mathrm{~cm}$ diameter) containing malt extract-peptone agar [MEPA: malt extract 3\% (Becton Dickison ${ }^{\ominus}$, Franklin Lakes,

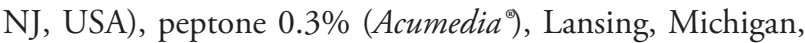
USA, agar 1.5\%, (Becton Dickison $\%$ ), Franklin Lakes, NJ, USA]. The fragments were then incubated at the respective temperatures until a colony of one treatment reached the edge of its Petri dish. Colony diameters were measured using calipers, and the mycelial mass was quantified by melting the medium in a microwave (Vargas-Isla and Ishikawa 2008). Five replicates were made at each temperature.

Discs of mycelium grown on PDA were transferred to 250 $\mathrm{mL}$ Erlenmeyer flasks with liquid malt extract-peptone (MEP) medium $[100 \mathrm{~mL}$ of $3 \%$ malt extract (Becton Dickinson, Franklin Lakes, NJ, USA), and $0.3 \%$ peptone (Acumedia ${ }^{\circ}$ ), Lansing, Michigan, USA]. The flasks were incubated at the respective experimental temperatures for 15 days, with six replicates. Later, the mycelial mass was separated by filtration and dried at $105^{\circ} \mathrm{C}$ to obtain a constant dry mass.

The experimental design was randomized with five treatments $\left(20,25,30,35\right.$ and $\left.40{ }^{\circ} \mathrm{C}\right)$ and six replicates. The data were analyzed using an analysis of variance (ANOVA) and the F-test, and averages were analyzed using Tukey's test at $5 \%$ probability.

Mycelial growth was tested on the following culture media: potato dextrose [PD: $200 \mathrm{~g}$ potato, $20 \mathrm{~g}$ dextrose (Nuclear ${ }^{\circ}$, Diadema, SP, Brazil), and distilled water to yield a $1000 \mathrm{~mL}$ final volume]; MEP and minimum medium (MM; Pontecorvo et al. 1953). PDA mycelium discs were transferred to $250 \mathrm{~mL}$ Erlenmeyer flasks with $100 \mathrm{~mL}$ of each respective medium and maintained at $30^{\circ} \mathrm{C}$ for 15 days. The mycelial mass were then filtered and dried at $105^{\circ} \mathrm{C}$ to obtain constant dry mass.

The experimental design was randomized with three treatments (PD, MEP and MM) and five replicates. The data were analyzed using an ANOVA and the F-test, with averages analyzed using Tukey's test at 5\% probability.

The Daldinia specimen was deposited in the INPA Herbarium (INPA 229859), and the PDA culture was deposited at the INPA Coleção de Microrganismos de 
Interesse Agrossilvicultural. The ITS1 sequence from the $5.8 \mathrm{~S}$ rRNA gene was deposited in the EMBL Nucleotide Sequence Database as FR848485.

\section{RESULTS AND DISCUSSION}

\section{Taxonomy}

Although more than 80 species of Daldinia are listed in the Index Fungorum (CABI 2012), this genus has only 25 valid species (Stadler et al. 2004) and is characterized by the formation of blackish or colored stromata that are 3-5 cm in diameter and varying shapes, with the tissue below the perithecial layer composed of alternating zones (Guzmán 1977; Ju et al. 1997).

According Pereira et al. (2010), only four Daldinia species have been reported in Brazil: D. caldariorum Henn., D. clavata Henn., D. concentrica, and D. eschscholtzii (Ehrenb.) Rehm. Daldinia caldariorum, D. concentrica and D. eschscholtzii were reported in Amazonas State, with D. caldariorum and D. concentrica in the municipality of Aripuanã and D. eschscholtzii in the municipality of Manicoré (Silveira and Rodrigues 1985). Daldinia clavata was reported in Santa Catarina State in 1892, in the municipality of Blumenau (Ju et al. 1997). The key below shows how the species differ.

\section{Key to Daldinia spp. reported in Brazil (according to Ju et al. 1997)}

1. Stromata cylindrical to somewhat clavate; Perithecia obovoid, $0.3-0.5 \mathrm{~mm}$ diam $\times 0.6-1 \mathrm{~mm}$ high; Ascospores $8-11.5 \times(3.5-) 4-5.5 \mu \mathrm{m}$, straight germ slit spore-length, perispore dehiscent in $10 \% \mathrm{KOH}$ D. clavata

1. Stromata turbinate, placentiform, spherical, or depressed-spherical

2

2. Perithecia obovoid, $0.2-0.5 \mathrm{~mm}$ diam $\times 0.5-0.8 \mathrm{~mm}$ high; Ascospores 8-11 $(-12) \times 4-5.5 \mu \mathrm{m}$, straight germ slit spore-length, perispore indehiscent in $10 \%$ $\mathrm{KOH}$ D. caldariorum

2. Perithecia tubular 3

3. Perithecia $0.3-0.5 \mathrm{~mm}$ diam $\times 1-2 \mathrm{~mm}$ high; Asci

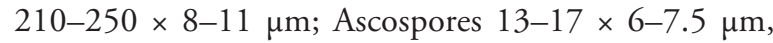
with slightly sigmoid germ slit spore-length on convex side

D. concentrica

3. Perithecia $0.3-0.4 \mathrm{~mm}$ diam $\times 1-1.5 \mathrm{~mm}$ high; Asci 160 $195 \times 7-9 \mu \mathrm{m}$; Ascospores 10-14 (-15.5) × 5-6.5 $\mu \mathrm{m}$, straight germ slit spore-length.

D. eschscholtzii

\section{Daldinia eschscholtzii (Ehrenb.: Fr.) Rehm, Ann. Mycol. 2: 175. 1904.}

Stromata placentiform to hemispherical, sessile, solitary, smooth, 3-6 cm diam $\times 1-3 \mathrm{~cm}$ high; surface brown vinaceous; without apparent $\mathrm{KOH}$-extractable pigments; the tissue between perithecia brown; the tissue below the perithecial layer composed of alternating zones, the darker zones dark brown, $0.2 \mathrm{~mm}$ thick, the lighter zones gray, persistent, $0.4 \mathrm{~mm}$ thick. Perithecia tubular, $0.3-0.4 \mathrm{~mm}$ diam $\times 1-1.2 \mathrm{~mm}$ high. Ostioles obsolete. Asci 165-189 $\times$ $7-8.5 \mu \mathrm{m}$, with apical ring bluing in Melzer's iodine reagent, discoid, $0.5 \mu \mathrm{m}$ high $\times 2 \mu \mathrm{m}$ broad. Ascospores dark brown, unicellular, ellipsoid-inequilateral, 10.5-12 × 5-6 $\mu \mathrm{m}$, with straight germ slit spore-length on convex side; perispore dehiscent in $10 \% \mathrm{KOH}$, smooth.

\section{Specimen examined, Brazil: Amazonas, Manaus, National Institute of Amazonian Research (INPA) 17.V.2008, leg. K.T. Yuyama and N.K. Ishikawa, on undetermined dead wood (INPA 229859).}

Notes: Daldinia eschscholtzii was first reported in the Philippines (as D. eschscholtzii) and considered a pantropical species (Ju et al. 1997). Daldinia eschscholtzii presents similarities with $D$. concentrica, but differs by having a straight vs. sigmoid germ slit, smaller ascospores (10.5-12 $\times$ 5-6 $\mu \mathrm{m}$ vs. $13-17$ x 6-7.5 $\mu \mathrm{m}$ ), and a stromatal surface with unpapillate ostioles vs. slightly papillate, and $\mathrm{KOH}$-extractable pigments not seen vs. $\mathrm{KOH}$-extractable pigments lively to dark purple (Ju et al. 1997; Stadler et al. 2004). Van der Gucht (1993) reported the ascospore perispore of D. eschscholtzii with coil-like ornamentation vs. smooth in $D$. concentrica, and sporulating gray region in the first and ochraceous in the second.

\section{Phylogenetic analysis}

A comparison of ITS sequences of ribosomal DNA (rDNA) from the studied specimen of D. eschscholtzii with those of GenBank specimens showed high similarity (99\%), corroborating the morphological identification. Figure 2 shows that the groupings of Daldinia species were consistent, with high bootstrap values, indicating a high reliability correlation.

Two clades were observed in the phylogenetic tree: one comprised of $D$. caldariorum, $D$. clavata and $D$. eschscholtzii and the other of $D$. loculata (Lév.) Sacc., D. concentrica, $D$. fissa, D. decipiens Wollw. \& M. Stadler, D. petriniae Y.M. Ju, J.D. Rogers \& F. San Martín and D. childiae J.D. Rogers \& Y.M. Ju ( $H$. fragiforme outgroup).

Hsieh et al. (2005) cited the close relationship between Daldinia and Hypoxylon Bull., as they are both Xylariaceae, have well-developed stromata with multiple immersed perithecia, and show apical ring bluing in Melzer's iodine reagent. However, Daldinia has concentric zones in the stromata, whereas the zone in Hypoxylon is homogeneous (Hsieh et al. 2005). According to Ju et al. (1997), the concentric zones in Daldinia are an adaptation to store water. 
Although not in the same branch, the isolated specimen FR848485 was closer to isolates from D. eschscholtzii (AB284189 and GU199418), with a bootstrap value of 96, reinforcing the results obtained in the macro- and micromorphological analysis.

\section{Mycelial growth}

The D. eschscholtzii isolate studied showed growth at 20-40 ${ }^{\circ} \mathrm{C}$, with better radial growth at $35^{\circ} \mathrm{C}$ in MEPA medium (Figure 3). However, the greatest mycelial mass was obtained at 25 and $30^{\circ} \mathrm{C}$ in MEPA medium (Figure 4). In MEP medium, the best biomass results were obtained at 25

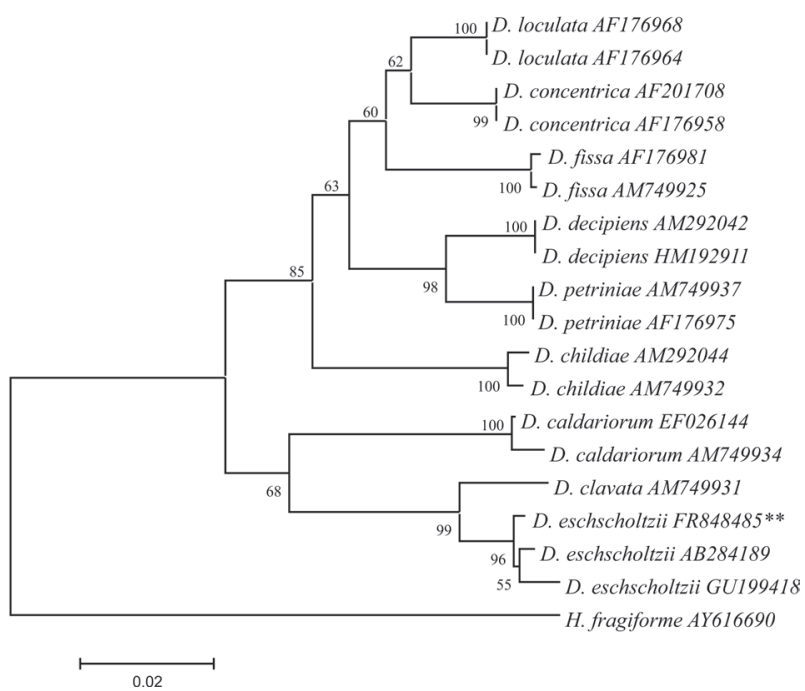

Figure 2 - Phylogenetic tree showing relationship between Daldinia eschscholtzii from Brazilian Amazon (FR848485) and other Daldinia species.

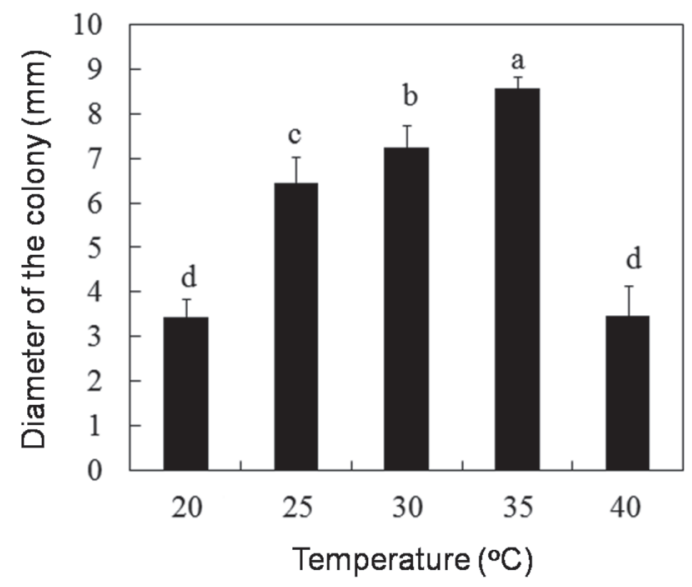

Figure 3 - Diameter of $D$ aldinia eschscholtzii cultivated in malt extract-peptone agar (MEPA) medium for seven days at different temperatures. Columns with the same letters did not differ significantly (Tukey's test, $P<0.05$ ). Average of five replicates. Bars $=$ standard deviation. and $30^{\circ} \mathrm{C}$ (Figure 5). Considering all three evaluations, the ideal temperature for mycelial growth appears to be $30^{\circ} \mathrm{C}$. Daldinia caldariorum showed similar results in PDA medium (Ng et al. 2010).

In D. concentrica, Boddy et al. (1985) observed the best mycelial growth at $25-30^{\circ} \mathrm{C}$, with growth ceasing at $35^{\circ} \mathrm{C}$. However, the isolate which we studied grew until $40^{\circ} \mathrm{C}$.

As an additional test, colonies of $D$. eschscholtzii that had been cultivated in Petri dishes for three days at $25^{\circ} \mathrm{C}$ were then cultured at $45^{\circ} \mathrm{C}$ for two days, and then brought again to 25 ${ }^{\circ} \mathrm{C}$. Growth halted under these conditions, but the cultures

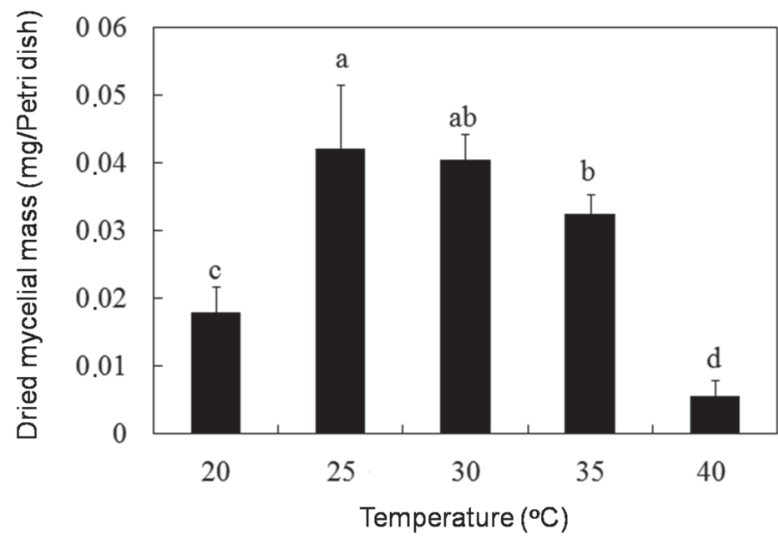

Figure 4 - Dried mycelial mass of Daldinia eschscholtzii cultivated in malt extract-peptone agar (MEPA) medium for seven days at different temperatures. Columns with the same letters did not differ significantly (Tukey's test, $\mathrm{P}<$ 0.05). Average of five replicates. Bars $=$ standard deviation.

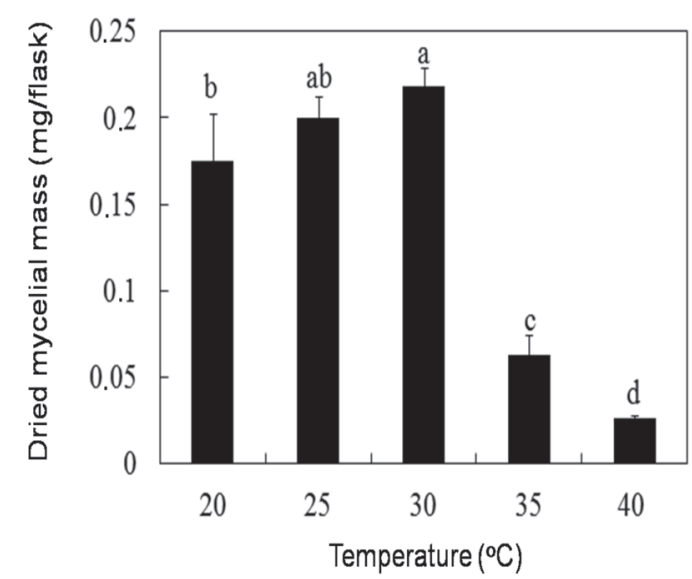

Figure 5 - Dried mycelial mass of Daldinia eschscholtzii cultivated in malt extract-peptone (MEP) medium for 15 days at different temperatures. Columns with the same letters did not differ significantly (Tukey's test, $P<0.05$ ). Average of six replicates. Bars $=$ standard deviation . 


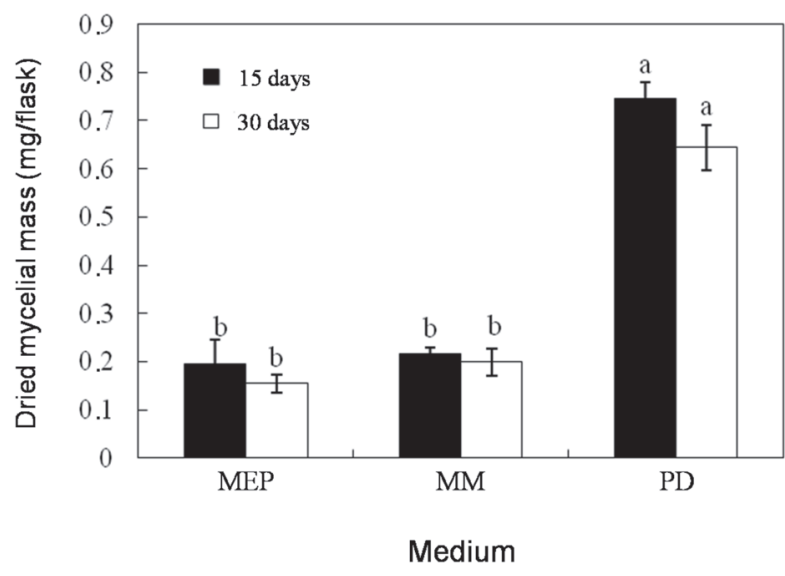

Figure 6 - Dried mycelial mass of Daldinia eschscholtzii cultivated in malt extract-peptone (MEP), minimum medium (MM), and potato dextrose (PD) media for 15 and 30 days at $30^{\circ} \mathrm{C}$. Columns with the same letters did not differ significantly (Tukey's test, $\mathrm{P}<0.05$ ). Average of six replicates. Bars $=$ standard deviation.

did not die. Mswaka and Magan (1999) grouped Trametes Fr. species into three classes based on optimal and maximum mycelial growth temperatures: (a) low-temperature group optimal growth at 25 and $30^{\circ} \mathrm{C}$, with no mycelial growth at $37^{\circ} \mathrm{C}$; (b) intermediate group - optimal growth at $30-37^{\circ} \mathrm{C}$, with no mycelial growth at $45^{\circ} \mathrm{C}$; and (c) high-temperature group - mycelial growth at $37-40^{\circ} \mathrm{C}$, with growth ceasing at $55^{\circ} \mathrm{C}$. Based on these criteria, our D. eschscholtzii isolate was in the intermediate group, which is an important factor in its survival and adaptation in the tropical climate, as the Amazon presents similar temperatures.

The $D$. eschscholtzii isolate that we studied showed the best mycelial growth in BD medium, followed by MEP and MM. No significant differences were observed in the percentage of growth after 15 and 30 days (Figure 6). After seven days at $25^{\circ} \mathrm{C}$, the colony was white with diffuse margins; 14 days later, spores (conidia) were produced on dark-gray mycelium (Figure 7). These observed characteristics are according to Ju a

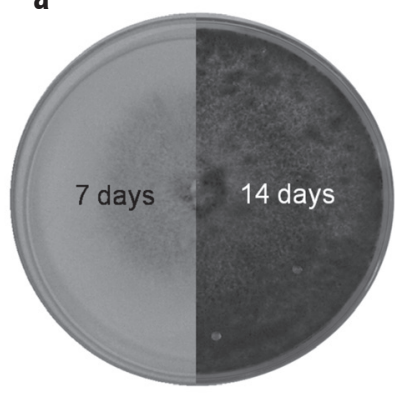

b

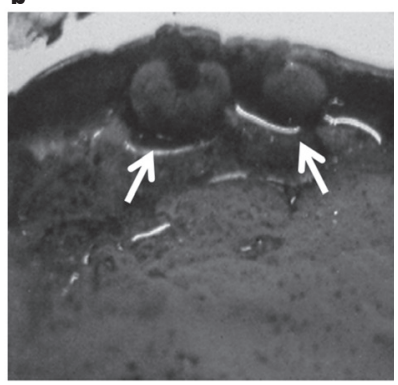

Figure 7 - Daldinia eschscholtzii. (a) Morphology of colonies after 7 and 14 days at $25^{\circ} \mathrm{C}$. (b) Stromata in potato dextrose (PD) medium after 42 days at $25^{\circ} \mathrm{C}$ (arrows). et al. (1997). Stromata measuring $0.5-1 \mathrm{~cm}$ were produced in PD medium (Figure 7), and concentric zones were seen. According to Ju et al. (1997), D. caldariorum, D. clavata, and D. eschscholtzii also produce stromata in vitro.

\section{CONCLUSIONS}

The specimen studied was identified as D. eschscholtzii. It showed the highest biomass growth in $\mathrm{PD}$ medium and mycelial growth between $20-40^{\circ} \mathrm{C}$ (optimum $30^{\circ} \mathrm{C}$ ).

\section{ACKNOWLEDGEMENTS}

The authors thank Dr. Marina Capelari and Biologist Tatiane Asai, from Instituto Biológico de São Paulo, for help with molecular analysis, the M.Sc. Ruby Vargas-Isla and Janaina da Costa Nogueira, for help in the experiments, and Dr. José Luiz Bezerra from Universidade Estadual de Santa Cruz (UESC) for helping with English corrections. Thanks to the Fundação de Amparo à Pesquisa do Estado do Amazonas (FAPEAM), Conselho Nacional de Desenvolvimento Científico e Tecnológico (CNPq) and Coordenação de Aperfeiçoamento de Pessoal de Nível Superior (CAPES) for financial support.

\section{REFERENCES}

Allport, D.C.; Bu'Lock, J.D. 1958. The pigmentation and cell-wall material of Daldinia sp. Journal of the Chemical Society, 1958: 4090-4094.

Allport, D.C.; Bu'Lock, J.D. 1960. Biosynthetic pathways in Daldinia concentrica. Journal of the Chemical Society, 1960: 654-662.

Anke, H.; Stadler, M.; Mayer, A.; Sterner, O. 1995. Secondary metabolites with nematicidal and antimicrobial activity from nematophagous fungi and ascomycetes. Canadian Journal of Botany, 73: 802-810.

Boddy, L.; Gibbon, O.M.; Grundy, M.A. 1985. Ecology of Daldinia concentrica: effect of abiotic variables on mycelial extension and interespecific interactions. Transactions of the British Mycological Society, 85: 201-211.

Braga-Neto, R. 2007. Guia de morfoespécies de fungos de liteira da Reserva Ducke. Programa de Pesquisas em Biodiversidade do Instituto Nacional de Pesquisas da Amazônia (PPBio/INPA). Manaus, AM, Brasil. 185 pp. Available from: http://ppbio.inpa. gov.br/Port/inventarios/guias/Guia_fungos_RFAD.pdd

Braga-Neto, R.; Luizão, R.C.C.; Magnusson, W.E.; Zuquin, G.; Castilho, C.V. 2008. Leaf litter fungi in a Central Amazonian forest: the influence of rainfall, soil and topography on the distribution of fruiting bodies. Biodiversity and Conservation, 17: 2701-2712.

Buchanan, M.; Hashimoto, T.; Asakawa, Y. 1995. Five 10-phenyl[11]-cytochalasans from a Daldinia fungal species. Phytochemistry, 40: 135-140. 
Buchanan, M.; Hashimoto, T.; Asakawa, Y. 1996a. Cytochalasins from a Daldinia sp. of fungus. Phytochemistry, 41: 821-828.

Buchanan, M.; Hashimoto, T.; Asakawa, Y. 1996b. A 10-phenyl[11]-cytochalasan from a species of Daldinia. Phytochemistry, 42: 173-176.

CABI Bioscience, 2012. Index Fungorum, (www.indexfungorum. org). Acesso em 15/01/2012.

Ferreira, M.E.; Grattapaglia, D. 1998. Introdução ao uso de marcadores em análise genética. EMBRAPA-CENARGEN Documento 20, Brasília, DF, Brasil. 220pp.

Gardes, M.; Bruns, T.D. 1993. ITS primers with enhanced specificity for basidiomycetes- application to the identification of mycorrhizae and rusts. Molecular Ecology, 2: 113-118.

Guzmán, G.H. 1977. Identificación de los hongos comestibles venenosos, alucinantes y destructores de la madera. Limusa, México. 225 pp.

Hashimoto, T.; Tahara, S.; Takaoka, S.; Tori, M.; Asakawa, Y. 1994 a. Structures of a novel binaphthyl and three novel benzophenone derivatives with plant-growth inhibitory activity from the fungus Daldinia concentrica. Chemical and Pharmaceutical Bulletin, 42 : 1528-1530.

Hashimoto, T.; Tahara, S.; Takaoka, S.; Tori, M.; Asakawa, Y. $1994 \mathrm{~b}$. Structures of daldinins A-C, three novel azaphilone derivatives from ascomycetous fungus Daldinia concentrica. Chemical and Pharmaceutical Bulletin, 42: 2397-2399.

Hashimoto, T.; Asakawa, Y. 1998. Biologically active substances of Japanese inedible mushrooms. Heterocycles, 47: 1067-1110.

Hingley, M.R. 1971. The ascomycete fungus, Daldinia concentrica as a habitat for animals. Journal of Animal Ecology, 40: 17-32.

Hsieh, H.-M.; Ju,Y.-M.; Rogers, J.D. 2005. Molecular phylogeny of Hypoxylon and closely related genera. Mycologia, 97: 844-865.

Johannesson, H. 2000. Ecology of Daldinia spp. with special emphasis on Daldinia loculata. Doctoral thesis, Swedish University of Agricultural Sciences, Uppsala, Sweden. 43pp.

Ju, Y.-M.; Rogers, J.D.; Martín, F.S. 1997. A revision of the genus Daldinia. Mycotaxon, 59: 243-293.

Lee, I.-K.; Seok, S.-J.; Kim, W.-G.; Yun, B.-S. 2006. Diaporthin and orthosporin from the fruiting body of Daldinia concentrica. Mycobiology, 34: 38-40.

Luizão, R.C.C.; COSTA, E.S.; Luizão, F.J. 1999. Mudanças na biomassa microbiana e nas transformaçôes do nitrogênio do solo em uma sequência de idades de pastagens após derruba e queima da floresta na Amazônia Central. Acta Amazonica, Manaus, 29: 43-56.

Moncalvo, J.-M.; Lutzoni, F.M.; Rehner, S.A.; Johnson, J.; Vilgalys, R. 2000. Phylogenetic relationships of Agaric Fungi based on nuclear large subunit ribosomal DNA sequences. Systems Biology, 49: 278-305.

Morales, O.; Medel, R.; Guzmán, G. 2006. Primer registro de la comestibilidad de una especie de Daldinia (Ascomycota). Revista Mexicana de Micologia, 23: 103-105.

Mswaka, A.Y.; Magan, N. 1999. Temperature and water potential relations of tropical Trametes and other wood-decay fungi from the indigenous forests of Zimbabwe. Mycological Research, 103: 1309-1317.

Ng, I.-S.; Chen, P.T.; Ji, Y.-M.; Tsai, S,-W. 2010. Novel cellulase screening and optimal production from the wood decaying Xylariaceae: Daldinia species. Applied Biochemistry and Biotechnology, 1-11.

Pereira, J.; Silveira, R.M.B.; Trierveiler-Pereira, L.; Loguercio-Leite, C. 2010. Xylariales. p.160. In: Forzaa, R.C. et al. Catálogos de plantas e fungos do Brasil. Instituto de Pesquisas Jardim Botânico do Rio de Janeiro, Rio de Janeiro.

Pontecorvo, G.; Roper, J.A.; Hemmons, L.M.; McDonald, K.D.; Bufton, A.W.J. 1953. The genetics of Aspergillus nidulans. Advances in Genetics, 5: 141-238.

Qin, X.-D.; Liu, J.-K. 2004a. Three new homologous 3-Alkyl-1,4benzoquinones from the fruiting bodies of Daldinia concentrica. Helvetica Chimica Acta, 87: 2022-2024.

Qin, X.-D.; Liu, J.-K. 2004b. Natural aromatic steroids as potential molecular fossils from the fruiting body of the Ascomycete Daldinia concentrica. Journal of Natural Products, 67: 2133-2135.

Qin, X.-D.; Dong, Z.-J.; Liu, J.-K.; Yang, L.-M.; Wang, R.-R.; Zheng, Y.-T.; Lu, Y.; Wu, Y.-S.; Zheng, Q.-T. 2006. Concentricolide, an anti-HIV agent from the Ascomycete Daldinia concentrica. Helvetica Chimica Acta, 89: 127-132.

Quang, D.N.; Hashimoto, T.; Tanaka, M.; Baumgartner, M.; Stadler, M.; Asakawa, Y. 2002a. Concentriols B, C and D, three squalenetype triterpenoids from the ascomycete Daldinia concentrica. Phytochemistry, 61: 345-353.

Quang, D.N.; Hashimoto, T.; Tanaka, M.; Baumgartner, M.; Stadler, M.; Asakawa, Y. 2002b. Chemical constituents of the Ascomycete Daldinia concentrica. Journal of Products, 65: 1869-1874.

Silveira, V.D.; Rodrigues, K.F. 1985. Levantamento preliminar de Xylariaceae na Amazônia. Acta Amazonica, 15: 7-27.

Singer, R. 1984. Adaptation of higher fungi to varzea conditions. Amazoniana, 8: 311-319.

Singer, R.; Araujo, I. 1979. Litter decomposition and ectomycorrhiza in Amazonian forests. 1. A comparison of litter-decomposing and ectomycorrhizal Basidiomycetes in latosol-terra-firme rain forest and white sand podzol campinarana. Acta Amazonica, 9: 25-41.

Singer, R.; Araujo, I., Ivory, M.H. 1983. The ectotrophically mycorrhizal fungi of the neotropical lowlands, especially Central Amazonia (Litter decomposition and ectomycorrhiza 2). Beihefte zur Nova Hedwigia, 77: 1-339.

Stadler, M.; Baumgartner, M.; Grothe, T.; Muhlbauer, A.; Seip, S.; Wollweber, H. 2001a. Concentricol, a taxonomically significant triterpenoid from Daldinia concentrica. Phytochemistry, 56: 787-793.

Stadler, M.; Wollweber, H.; Muhlbauer, A.; Henkel, T.; Asakawa, Y.; Hashimoto, T.; Rogers, J.D.; Wetzstein, H.-G.; Tichy, H.V. 2001b. Secondary metabolites profiles, genetic fingerprints and taxonomy of Daldinia and allies. Mycotaxon, 527:379-429.

Stadler, M.; Wollweber, H.; Jager, W.; Briegert, M.; Venturella, G.; Castro, J.M.; Tichy, H.-V. 2004. Cryptic species related to Daldinia concentrica and D. eschscholzii, with notes on D. bakeri. Mycological Research, 108: 257-273. 
Tarman, K.; Palm, G.j.; Porzel, A.; Merzweiler, K.; Arnold, N.; Wessjohann, L.A.; Unterseher, M.; Lindequist, U. 2012. Helicascolide C, a new lactone from an Indonesian marine algicolous strain of Daldinia eschscholzii (Xylariaceae, Ascomycota). Phytochemistry Letters, 5: 83-86.

Van der Gucht, K. 1993. Spore ornamentation makes a nice difference: Daldinia eschscholzii and Daldinia concentrica, p. 309-310. In: Isaac, S.; Frankland, J.C.; Watling, R.; Whalley, A.J.S. (Eds.). Aspects of Tropical Mycology. Cambridge University Press, Cambridge.

Vargas-Isla, R.; Ishikawa, N.K. 2008. Optimal conditions of in vitro mycelial growth of Lentinus strigosus, an edible mushroom isolated in the Brazilian Amazon. Mycoscience, 49: 215-219.

Wang, F.; Liu, J.-K. 2004. A pair of novel heptentriol stereoisomers from the Ascomycete Daldinia concentrica. Helvetica Chimica Acta, 87: 2131-2133.

White, T.J.; Bruns, T.; Lee, S.; Taylor, J. 1990. Amplification and direct sequencing of fungal ribosomal RNA genes for phylogenetics, p. 315-322. In: Innis, M.A.; Gelfand, D.H.; Sninsky, J.J.; White, T.J. (Eds.). PCR Protocols: A Guide to Methods and Applications. Academic Press, San Diego.

Zhang, Y.L.; Ge, W.M.; Zhao, W.; Dong, H.; Xu Q.; Li, S.H.; Li, J.; Zhang, J.; Song, Y.C.; Tan. R.X. 2008. Unprecedented immunosuppressive polyketides from Daldinia eshscholzii, a mantis-assoated fungus. Angewandte Chemie International Edition, 47: 5823-5826.

Zhang, Y.L.; Zhang J.; Jiang N.; Lu, Y.H.; Wang, L.; Xu, S.H.; Wang, W.; Zhang, G.F.; Xu, Q.; Ge. H.M.; Ma, J.; Song, Y.C.; Tan, R.X. 2011. Immunosuppressive polyketides from mantisassociated Daldinia eschscholzii. Journal of the American Chemical Society, 133: 5931-5940.

Recebido em: 14-10-2011

Aceito em: 13-04-2012 